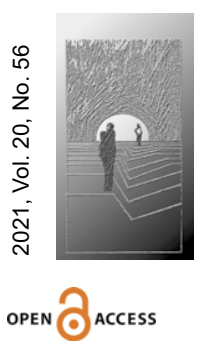

\title{
Jesuit Upbringing as Prevention Against Fundamentalism, Bigotry and Pharisaism
}

\begin{abstract}
RESEARCH OBJECTIVE: The objective of the work is presenting the pseudoreligion F hypothesis created by a Czech theologian, sociologist and philosopher Tomáš Halík. The second part of the text presents the challenges of Jesuit upbringing which can be understood as a possible strategy and prevention against the pseudoreligion $\mathrm{F}$.
\end{abstract}

THE RESEARCH PROBLEM AND METHODS: Pseudoreligion $F$ is a hypothesis through which Tomáš Halík interprets similarities among several pathological phenomena of the contemporary social culture as well as Christian religiosity. The key solution is the critical education and dialogue. It is the system of Jesuit education that can be understood as a tested preventive strategy. Critical analysis of the beginnings of Jesuit education shows that this is still a valid method of teaching and upbringing.

THE PROCESS OF ARGUMENTATION: In the first part of the work, the pseudoreligion F hypothesis was presented, as well as some related theses. The objective of the first part is describing the sociological and philosophical criticism of contemporary religious pathologies. In the second part of the text, we will focus on the key tasks and challenges of Jesuit pedagogy.

RESEARCH RESULTS: Contemporary religious pathologies, such as fundamentalism, bigotry, etc. threaten Christianity as they distort the ideals of the Gospel to achieve short-term goals. In the context of Christianity, such pathologies also include clericalism and, more broadly, pharisaism. Critical thinking about these issues encourages us to search for strategies that can help "extinguish the fire." One of such strategies is integral humanist education which is also represented by Jesuit education.

CONCLUSION, INNOVATION, AND RECOMMENDATION: Despite the ambiguity of this term, critical thinking is considered to be the key tool for preventing fanaticism, fundamentalism, extremism, etc. The research is to show that critical education mainly refers to the complexity and integral anthropological line. Education and Jesuit education has a rich tradition based on the Ignatian and Jesuit spirituality. The return to those sources of thinking is not just a challenge in the Jesuit thinking about the very intellectual apostolate, but it is also a possible strategy of educating people for true critical thinking.

$\rightarrow$ KEYWORDS: FANATICISM, FUNDAMENTALISM, PHARISAISM, CRITICAL THINKING, JESUIT EDUCATION, 


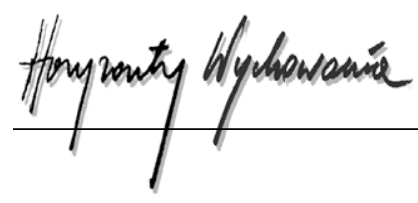

\section{STRESZCZENIE}

\section{Wychowanie jezuickie jako profilaktyka przeciw trzem F (fundamentalizmowi, bigoterii i faryzeizmowi)}

CEL NAUKOWY: Celem pracy jest przedstawienie hipotezy pseudoreligii F, której autorem jest czeski teolog, socjolog i filozof Tomáš Halík. Druga część tekstu przedstawia wyzwania wychowania jezuickiego, które można rozumieć jako potencjalną strategię i profilaktykę wobec pseudoreligii F.

PROBLEM I METODY BADAWCZE: Pseudoreligia F to hipoteza, za pomocą której Tomáš Halík interpretuje podobieństwa między kilkoma patologicznymi zjawiskami współczesnej kultury społecznej, a także religijności chrześcijańskiej. Kluczowym rozwiązaniem jest krytyczna edukacja i dialog. To właśnie system wychowania jezuickiego można rozumieć jako sprawdzoną strategię profilaktyczną. Krytyczna analiza początków wychowania jezuickiego pokazuje, że jest to wciąż aktualna metoda edukacji i wychowania.

PROCES WYWODU: W pierwszej części pracy przedstawiono hipotezę pseudoreligii $F$ oraz tezy pokrewne. Celem pierwszej części jest przybliżenie socjologiczno-filozoficznej krytyki współczesnych patologii religijnych. W drugiej części tekstu skupię się na kluczowych zadaniach i wyzwaniach pedagogiki jezuickiej.

WYNIKI ANALIZY NAUKOWEJ: Współczesne patologie religijne, takie jak fundamentalizm, bigoteria itp. zagrażają obliczu chrześcijaństwa, wypaczając ideały ewangelii na rzecz krótkoterminowych celów. W kontekście chrześcijaństwa do takich patologii można dodać klerykalizm i szerzej faryzeizm. Krytyczne myślenie o tych kwestiach prowadzi do poszukiwania strategii, które pomogą „ugasić ogień". Jedną z takich strategii jest integralna edukacja humanistyczna, którą reprezentuje także wychowanie jezuickie.

WNIOSKI, INNOWACJE, REKOMENDACJE: Pomimo niejasności tego terminu krytyczne myślenie jest uważane za kluczowe narzędzie zapobiegania fanatyzmowi, fundamentalizmowi, ekstremizmowi itp. Badanie ma na celu wykazanie, że edukacja krytyczna dotyczy przede wszystkim złożoności i integralnej linii antropologicznej. Szkolnictwo jezuickie ma swoją bogatą tradycję, opartą na duchowości ignacjańskiej i jezuickiej. Powrót do tych źródeł myślenia jest nie tylko wyzwaniem w jezuickim myśleniu o samym apostolacie intelektualnym, ale także potencjalną strategią wychowania do naprawdę krytycznego myślenia.

$\rightarrow$ SŁOWA KLUCZOWE: FANATYZM, FUNDAMENTALIZM, FARYZEIZM, KRYTYCZNE MYŚLENIE, WYCHOWANIE JEZUICKIE

\section{Introduction}

A part of the contemporary liquid modernity is the increasing fragmentation of the society, as well as the polarization and development of pathological social phenomena, such as bigotry, fundamentalism, etc. These phenomena have a particular characteristic feature 
that may be defined as "ecumenical pathology." It is present in the whole range of social areas, such as religion, politics, culture, as well as art, etc. The attempts to solve those problems are a challenge not only for selected areas of theoretical and practical reflection, but also for a whole range of interdisciplinary studies. Problems such as fundamentalism, bigotry and polarization are defined in different manners in various areas of research. However, there is a rare consensus in terms of one issue, i.e. that it is better to prevent the pathological manifestations of social phenomena than to catalyze them in the society. In this text, we will try to indicate the opportunity to prevent pathological phenomena which, in theory and practice, represent the Jesuits' upbringing and intellectual formation. Critical, free and creative thinking, which helps prevent social diseases, is also a common challenge in the contemporary Jesuit thinking.

\section{Pseudoreligion $F$ according to Tomáš Halík}

The author of the concept of pseudoreligion $\mathrm{F}$ is the Czech thinker Tomáš Halík (cf. Halík, 2020a, pp. 51-61; Halík, 2020b). In his brief essay on this subject, which has been published in several language versions (Czech, Slovakian, Polish, etc.), he presents pseudoreligion $\mathrm{F}$ as a hypothesis which aims at capturing the common features of different contemporary religious pathologies.

According to Tomáš Halík, there are various manifestations of pseudoreligion $F$, and his essay certainly does not describe all the pathological expressions of religious life in the modern Central Europe. Apart from fundamentalism which, as a pathological ecumenism, combines different Christian trends and is recognisable in the world's main religions, we can also see fanaticism which results from reducing Christian religion to cultural and ethical conflicts (abortion, LGBTQ+, sex agenda). In terms of theology and spirituality, Christianity is often reduced to the area of regulations and norms related to sexual life, which significantly impoverishes the religion's potential to make peace. The control and interference with intimacy is legitimized by the caricature of fighting with materialism and individualism that restores dualist tendencies and the phenomenon duplex ordo. Also, we can witness several expressions of pharisaism, which are related to the conflict between regulating the Catholic theology, Christian religion and culture with the phenomenon of secularization and desecularization which is manifested in several manners.

In the context of Catholic religiousness, desecularization is mainly expressed in the renaissance of integralist tendencies, the return of traditionalism, and the campaign of open culture towards the modern society (cf. Petráček, 2016, pp. 15-53; Petráček, 2015, pp. 11-32). Then, open questioning of the vectors of the Second Vatican Council leads to hidden and open criticism of the Pope, standard theological views, and correlates with the creation of legalism and clericalism in the Church. These and similar phenomena have one thing in common: 


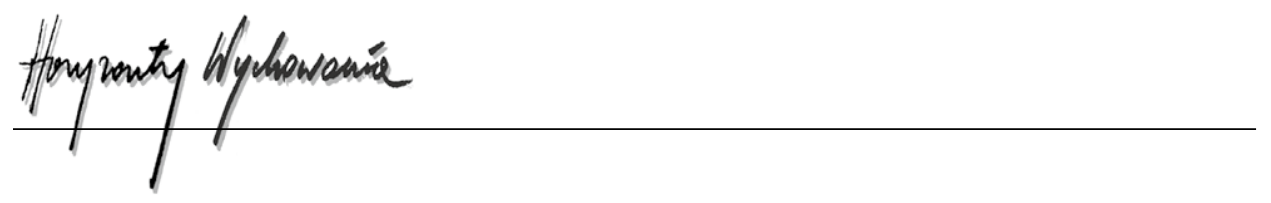

Despite the differences, they are, first of all, similar in terms of mentality, which is characterised by: selective and purposeful usage of religious rhetoric that is contrary to the ethical core of those religions; resistance towards the historic and hermeneutic approach to religion; intolerance ("being the owner of the whole truth"); combining religion with the interests of power of particular political circles, etc. Selective approach to religious resources and "religious ecstasy" (loss of the original context) makes this phenomenon a lay "civil" and political religion ("civil religion"). Its content is of secondary importance; the main connecting element is the emotional load (Halík, 2020b).

While religions lose their universalist claims and are often forced to moderate their conflicts for pathological expressions of religiousness, the difference between the lay world and the theological perception of the world is a stimulating source of reaction. Pseudoreligion $\mathrm{F}$ is an ostentatious response and selection of the spirituality of escape and of the rapidity of the changing world and religious bigotry. However, the ability of pseudoreligion $F$ to react (although such a reaction is non-dialogic and negative) to the changing world is, paradoxically, more efficient than the power of critical thinking or the ability of theology to dialogue with natural and humanist sciences. It is natural that where theology asks questions and calls for dialogue, pseudoreligion $\mathrm{F}$ is limited to populist and simplified instructions the effectiveness of which are shifted towards intellectual modesty that is so desired in the academic environment. Tomáš Halík identifies this threat and emphasizes that its vitality is also connected with the Church's passiveness and religious illiteracy.

However, in reality it is necessary to become distanced to the manifestations of "pseudoreligion F" which push the critical audience away from the Church and, at the same time, attract and fascinate people who want simple answers to complex questions and immovable "axioms."

It is necessary to indicate alternative examples of Christian groups which honestly aim at intelligent, reasonable interpretation of faith, development of one's own spiritual life (contemplative approach to the reality), active participation of Christians in the civil society, cultural life, and education, as well as environment initiatives that reinforce ecumenism, interreligious and intercultural dialogue (Halík, 2020b).

Thus, pseudoreligion $\mathrm{F}$ is a working hypothesis through which prof. Halík tries to elicit important features from different pathological phenomena which are directly or indirectly related to the world of religion.

There is no doubt that the basic assumption for all kinds of pathologies is a methodical utopianism, which is why we can speak about a series of common features the identification of which is the first step to their possible correction. The parasitic nature of pseudoreligion $\mathrm{F}$ seems to be of key importance. Those pathological phenomena appear due to the negative understanding of the identity of religion and spirituality. Fanaticism, fundamentalism, and eventually, pharisaism, are generated because of the lack of positive features of contemporary religiousness although it is a positive definition that builds a healthy identity of a Christian or a member of another religious denomination. Where 
there are no positive contents, there is only a space for a negative definition and resistance to what we oppose. But how can we prevent those social pathologies?

\section{Challenges and tasks of Jesuit upbringing according to A. Nicolás}

One of typical features of Jesuit pedagogy is a strong humanist ideal. However, a person's return to the essence of philosophical reasoning within this context is connected with the role of spirituality and theological anthropology, as well as with the influence of Renaissance humanism.

The Renaissance meaning of an individual, which already appears among Renaissance humanists, and then in the Renaissance Platonism and humanism, is a philosophical impulse which was adopted and transformed into pedagogical objectives by the Jesuit spirituality (cf. Kristeller, 1961, pp. 120-139; O’Malley, 2015, pp. 1-33; Jeník, 2015, pp. 5-27).

However, the return to spirituality as the source of education and upbringing is also visible in the current trends, challenges and concepts of the Jesuit thought, as well as in the documents of the 36th General Congregation (1st Decree). A clear call for the formation can be found in the documents of the last General Congregation (1st Decree) which is to facilitate a more righteous society, i.e. it is to reduce the resources of old-new "intellectual civilization diseases" such as fanaticism and fundamentalism (cf. Documents of the 36th General Congregation of the Society of Jesus, 2017, §26-28). Fundamentalism and various forms of xenophobia in the changing world are an accompanying sign of polarization, which results from the loss of aiming at the common good. Religious fanaticism in Christianity is its caricature and significantly contributes to such polarization. However, education only aims at increasing erudition. A holistic formation should include both the intellectual apostolate and the social and spiritual aspect.

The Ignatian and Jesuit spirituality is the key source of Jesuit education. Due to the times in which St. Ignatius was formed, Jesuit spirituality and its application match the humanist objective of a person's integral development as a human being is not only developing as a material being, but also as a person (cf. O'Malley, 2015, pp. 7-23). The integral approach to a person in the Ignatian spirituality results from his/her "presence" in the two worlds, or (in order to avoid hidden dualism) from the view of a man who is created in the world in which the presence of God is reflected. A typical feature of Ignatian and Jesuit spirituality is contemplating God in everything. Other features include indifference to material things and freedom to make decisions. However, God, whom we contemplate in all things, also appears exceptionally in the motif of incarnation, as a result of which the meaning of materiality and bodiliness becomes cancelled (cf. Martin, 2012, p. 15). Since upbringing is a formation, too, its objective is not only theory, and Jesuit upbringing goes beyond the borders of applying the theory that flows from the authority of Aristotle (cf. Aristotelés, 2008, 982a-983a20, pp. 36-39). Thus, the emphasis on the objective of education, which includes leading a person towards richer life in joy, 


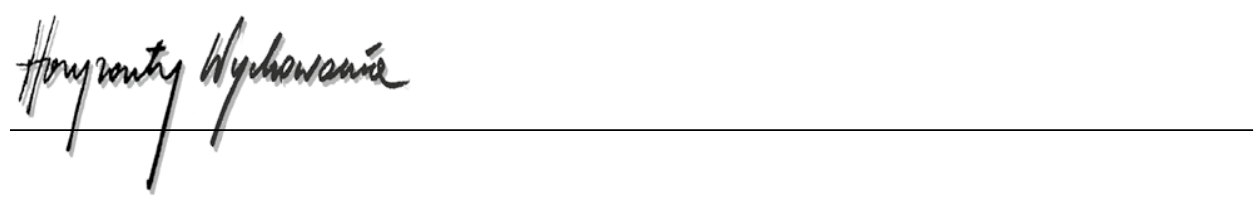

not only leads to the professionalization of talents and appreciation of theory, but - first of all - to showing a student the perspective of valuable life. These pedagogical objectives result from constantly valid foundations of the Jesuit spirituality, as we read in the Spiritual Exercises of St Ignatius (cf. Ignác z Loyoly, 2005, §23). The principle and foundation clearly direct the educational process and mark the place both for theory and for practice.

Adolfo Nicolás talks about the objective of Jesuit education as upbringing and learning that helps the student organize their hierarchy of values and respond to the challenges of the globalization era. The context of the globalized era, which is full of the above-mentioned pathologies and civilization pains (xenophobia, injustice, religious fundamentalism, bigotry, etc.), is another occasion for Jesuit education to show the benefits from long and tested strategy: the depth of education and spirituality (cf. Nicolás, 2013a, pp. 31-32). The depth of education, which draws on the critical interpretation of its own tradition - it learns from its own mistakes and reaches for the richness of Christian tradition - is a constructive inspiration for creativity which is able to change the pathological potential of religious beliefs into its opposite: into a peaceful and integral humanist force.

In his speech given in Mexico City in 2010, Nicolás also developed the concept of making education and imagination more profound, and he emphasized the need for creativity and spirituality which are the basis for the Jesuit educational strategy. He underlined three tasks: making thinking more profound, complexity and universal nature of Jesuit education, and typically Jesuit spiritual gift of service (cf. Nicolás, 2011, p. 6).

\section{Becoming absorbed in thinking}

Going deeper, becoming absorbed in thinking and imagination, is the key motif of the Spiritual Exercises. Such education goes beyond the dogmatism of reducing thinking sources only to the areas of religious beliefs or only to rationalist thinking. Imagination is an original, but also complex fulfilment of the role of rationality in human life, which is emphasized by the Aristotelian-Scholastic philosophy. Also, making imagination more profound gives pedagogy the meaning of subjectivity, as it is connected with the uniqueness of the relationship between a person and God. Thus, respecting this uniqueness opens the space for tolerance and pluralism. Becoming absorbed in imagination - imagination based on a person's subjective opportunities - and extending thinking is much more than critical thinking based on consistent calculation. In the Jesuit thought, therefore, a rare element appears, i.e. being sensitive to the uniqueness and dignity of each free being. However, free beings may act wrong, and then a person's mistake (sinfulness) is not just a wise strategy, but a significant change in the upbringing perspective. Faultlessness is not the objective, and justice as the result of upbringing is also inspired by mercy, which is how freedom becomes elevated again.

Brian B. Pinter talks about more profound thinking the objective of which is redefining success (cf. Pinter, 2014, pp. 15-17). Such thinking is not for career. Obviously, this 
is not a negation of the importance of the world, material objectives and work. Instead, it involves a better hierarchical organisation of the objectives for which we study and live. The success Pinter thinks about is based on the strict application of the Ignatian spirituality, and, in particular, the principles of the foundation. Redefinition of success is the re-emphasis of those values the achievement of which is always a greater success than their absence, only at the cost of material goods.

However, it is worth paying attention to an important imagination issue: imagination is not a sign of utopian thinking or dreaming, but it has to be derived from the reality that treats a person as a mystery. Imagination that grows out of the reality and that includes not only human greatness, but also sinfulness, can transform both imagination and the reality itself. Imagining (what can be achieved) fuels the reality, which inevitably reduces that reality to the limits of rationality and faith.

Imagination methodically leads us to separating those issues that are justified as they are not just an utopian fantasy. That is why, unrealistic visions cannot be perceived as making imagination more profound. This motif of the role of imagination is another heritage of the time in which the Jesuits' spirituality was born. It is the humanist tradition of the Jesuit education which inspires us to think that upbringing is not just a professionalization of talents, but it is the ability to accept and perceive the world the way it is and the way it could be. To put it more simply: constructive imagination is the source of constructive service.

Thus, imagination which is the source of creativity and is strictly related to the realistic perception of the world, has significant social consequences. According to Pinter, contrary to the "escape" into philosophical-theoretical issues, imagination and reality should send us to "smaller" but more urgent problems (cf. Pinter, 2014, p. 17). Imagination is to make a human being more sensitive, especially to the problems that surround a given person. We may simply say that the inconvenience of unsuccessful confrontation with global problems may be prevented by focusing on problems that are smaller, but, paradoxically, more difficult.

Pinter understands this emphasis on imagination as the reason for self-criticism of the Catholic theology and pastoral success, because, in his opinion, Catholic thinking (and not only that) is often closed or oriented at global problems. If we want to think about redefining success, we have to self-critically look at the hypocrisy of the Christian practice.

Christian moral practice often focuses on the problems that may be perceived as fictional or secondary, and it is because of such artificial creation of problems (and, at the same time, enemies) that it often forgets about solving real difficulties. Real problems are perceived as less important because, as a suggestive conspiracy theory often claims today, there is a risk of more serious cultural and ethical problems. This hypocrisy of a kind of religious delay and dealing with secondary issues, such as reducing Christianity to the problem of sexuality, is connected with a critical challenge mentioned by Tomáš Halík who emphasizes the civil dimension of living the Christian faith. Christians are invited to live and cooperate "in a civil society, in cultural, educational and environmental 


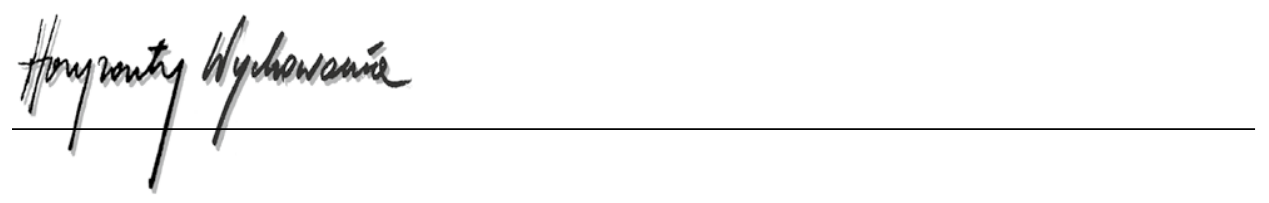

initiatives, in reinforcing ecumenism, as well as interreligious and intercultural dialogue. Christians should not be among those who weaken the society's resistance to populism, fake news and conspiracy theories" (Halík 2020b). Jesuit education and upbringing formation should be characterised by, inter alia, true solidarity and aiming at social justice that results from the invitation (command) to leave the comfort zone and go to the border which sometimes is not far away.

\section{Creativity as versatility}

The second challenge and task presented by Nicolás is searching for complexity, integrality and universality of Jesuit education. Rediscovering of this principle is connected with the already mentioned emphasis on the development of imagination and creativity in education. Searching for the answer to the question what Nicolás understands as the problem of imagination and creativity starts from the problem of globalization.

The issue of globalization is to be perceived as a system of reference indicated by Nicolás who calls us to a creative evaluation of facts. It is worth emphasizing that even in the face of the problems related to this phenomenon, he does not perceive the reality of a global village as something a priori negative. Not only the views of Nicolás, but also the current tendencies and perspectives presented in the 36th General Congregation show that the phenomenon of globalization is the movement that cannot be reversed. Instead, it is a challenge for our creativity and evangelization.

But what does it mean to go to the border, or what should we take with us while crossing the border? In this context, space is opened for perceiving the problem of tolerance as the starting point and key virtue. Pluralism is an ideal, but we cannot mistake it for relativism and simple tolerance. Tolerance, as a relationship of kindness and respect for others, is characterised by the same humanistic and Christian ideals. Such a concept of tolerance is in direct contrast with tolerance as the tolerance of otherness. The challenge mentioned by Nicolás with reference to the system of Jesuit schools is a deeper reflection on still valid humanistic foundations of pluralism which unify religious and lay beliefs in order to critically think about the world in which we all live. Indeed, the real tolerance does not result from anything else but deeper understanding and constant reflection on the question of who a man is. Thus, pluralism is not a relativism of superficiality, but, on the contrary, it is a conclusion connected with respecting a person's uniqueness and his/her call for the relationship with God and the world.

\section{Spirituality of service}

The third task and challenge is the return to the meaning of service and Christian life which is characterized by such forms of love as caritas and agape. The Ignatian and Jesuit spirituality is characterized by emphasizing the place of spirituality in the world 
and in life. Each spirituality is practical, but not everyone emphasizes integral development. A humanistic ideal of upbringing, which improves practice and life in itself, as well as education that helps one become open to the foreign world, has been a feature of the Jesuit thought from the very beginning.

The emphasis on cura personalis is a clear element in which the integral dimension of education is manifested. However, Jesuits inherited this motif and they were not the first to implement it in education. Cura personalis was already a characteristic of Renaissance humanists as the ideal of school life, and that was the inspiration for Jesuit colleges in the 17th century in the Old and New World (cf. Kristeller, 1961, pp. 120-139). Education and care for oneself should shape tolerance, respect and love. As Pinter adds, spirituality should not be separated from the reality of globalization in which we have to learn to coexist, as "there is no spirituality cut off life itself" (Pinter, 2014, p. 17).

Since the 16th century, Jesuit education has been shaped radically different than the school ideal of theoretical education. Jesuit education is much more avant-garde because of the fact that it includes the dimension of instrumentality. Theoretical education and knowledge are important, but they are not an Aristotelian objective as such. Instead, they are a way to live a richer life in the world. One of the signs of pragmatic understanding of the meaning of education is that Jesuit education was, at first, characterized by focusing on areas of natural philosophy and humanities other than theology. Because of that it was clear that the differentiation in spirituality influenced pedagogical objectives. Studies and education are to make us closer to the real meaning of life; to life in fuller joy in which one's imago dei potential is fulfilled. According to Nicolás, today's role of Jesuit education includes re-offering of an education ideal as a tool of service and not of benefit. Knowledge should not be an instrument of power or a professionalization of personal talents which only serve their owner (cf. Nicolás, 2011, p. 9). The access to Jesuit education is not a service for the elites which have special privileges, but - on the contrary - it is a tool for decreasing social injustice and segregation. Just like Nicolás, Pinter underlines that in the technocratic, university model of education, which emphasizes professional success, the ideal of solidarity is missing.

Dominic J. Balestra emphasizes that education for service will be effective if service is authentic. Jesuit education and cura personalis should aim at personal development, sensitivity and concentration, which will help everyone differentiate in life better (cf. Nicolás, 2013b, p. 32; Balestra, 2008, pp. 94-104). Balestra emphasizes the inner relationship between the role of cura personalis and the ideal of magis. Caring for a student in his/ her education and formation should lead to critical thinking, but also to the awareness and development of faith. This should give the student force to make personal decisions and choices, and to feel responsible for the world. However, education and upbringing should not be separated from spirituality, which lives above everyone who develops it. The success of Jesuit education is thus based on the validity and authenticity of spirituality, which is reflected in the quality of life of those who present it (cf. Balestra, 2008, pp. 94-104). 


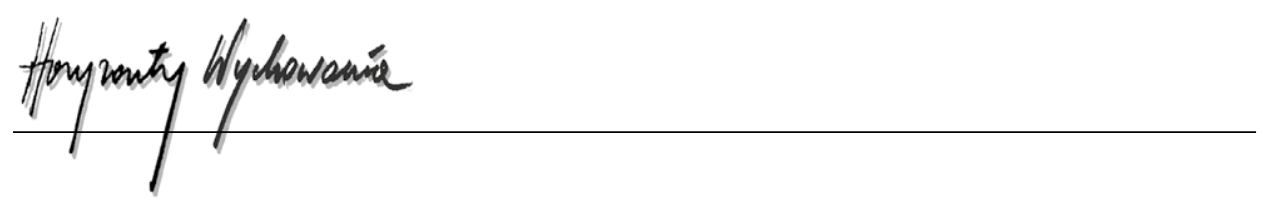

\section{Conclusion}

The continuous "mantra" of the need for critical education often boils down to the technocratic emphasis on STEM. However, we can rightfully ask whether the emphasis on this area of education will help us reduce fundamentalism or bigotry. A higher frequency of Maths lessons is certainly not harmful, but it does not make us resistant to fundamentalism, reductionism or dogmatism. Indeed, the objective of this text is not questioning the meaning of a critical debate and dialogue between humanities and natural sciences, which is stimulating and necessary for both areas. The objective is to show that the development of a complex personality is not the issue of emphasizing one area and limiting another. That is why, Jesuit education and schooling is characterized by constant aiming at the harmonious implementation of upbringing that helps us understand the world in which we live and which is being created. A typical feature of Jesuit education, especially in the 17th century, was paradoxically the secondary importance of theological faculties created at new universities. Such theological faculties were only created after the opening of faculties focused on various areas of natural sciences. A typical feature of Jesuit upbringing - aiming at the complexity and integral development of a person is included in the old-new strategy of preventing the F pseudoreligion and in the strategy aiming at true critical thinking. Being open to service, critical formulation of arguments, as well as openness to constant discussion and dialogue, are just a few features and tasks the fulfilment of which is a radical opposite to the pains of today's society. Becoming open to service and respect for the autonomy of another person encourages us to reject the dogmatic pharisaism of the truth owners. In turn, the quest for critically adequate thinking opens the space for such a dialogue that does not make others tools of our own convictions, but - on the contrary - it makes it possible for us to accept others in love. The spirit of delicacy and the meaning of service are strategic tasks in a natural contrast for demagogy and populism.

The tasks mentioned by the authors such as O'Malley, Nicolás, Balestra and others, show that the return to some spiritual gifts of Jesuit education is also a prescription for such a form of upbringing that may be an efficient prevention against intellectual civilization diseases, such as populism, fundamentalism, bigotry, various kinds of extremisms, religious or lay dogmatism, and, finally, typical ailments of Christians, such as clericalism. The only way to prevent the $\mathrm{F}$ pseudoreligion is to remain rooted in dialogue which is the key challenge specified by Pope Francis in the encyclical Fratelli tutti.

\section{BIBLIOGRAPHY}

Aristotelés. (2008). Metafyzika (A. Kř́žž, Trans.). Petr Rezek.

Balestra, D.J. (2008). Where loyalties lie? In G.W. Traub (ed.), A Jesuit education reader (pp. 94104). Loyola Press.

Documents of General Congregation 36 of the Society of Jesus. (2017). https://jesuits.eu/images/ docs/GC_36_Documents.pdf 
Halík, T. (2020a). Zkušenost pandemie a proměny křest'anství: Společensko-historický kontext "korona-krize" a jeho teologická reflexe. Studia Aloisiana, 3, 51-61.

Halík, T. (2020b, May 11). Pseudonáboženstvo F - príklad náboženskej patológie. https://www. aktuality.sk/clanok/839724/pseudonabozenstvo-f-priklad-nabozenskej-patologie-nazor/

Ignác z Loyoly. (2005). Duchovné cvičenia. Dobrá kniha.

Jeník, L. (2015). K teoretickým východiskám jezuitského vzdelávania. Studia Aloisiana, 6(4), 5-27.

Kristeller, P.O. (1961). Renaissance thought: The classic, scholastic, and humanist strains. Harper \& Row.

Martin, J. (2012). Jezuitský návod (takmer) na všetko. Dobrá kniha.

Nicolás, A. (2011). Challenges to Jesuit higher education today. Conversations on Jesuit Higher Education, 40(1), 1-4. http://epublications.marquette.edu/cgi/viewcontent.cgi?article=1651\&c ontext=conversations

Nicolás, A. (2013a). Stretnutie s pedagógmi, pracovníkmi a študentmi TFTU (Bratislava 26.11.2012). Provincialát Spoločnosti Ježišovej na Slovensku.

Nicolás, A. (2013b). A call for spiritual leaders: The Jesuit superior general on higher education. America. The Jesuit Review, 209(14), 25-28.

O'Malley, J.W. (2015). Jesuit school of humanities yesterday and today. Studies in The Spirituality of Jesuits, 47(1), 1-33.

Petráček, T. (2015). Sylabus omylů piánské církve: Církev, hereze a Il. vatikánský koncil. Salve 4, 11-32.

Petráček, T. (2016). Církev, tradice, reforma: Odkaz Druhého vatikánského koncilu. Vyšehrad.

Pinter, B.B. (2014). Redefining success. America. The Jesuit Review, 210(16), pp. 15-17.

\section{Copyright and License}

This article is published under the terms of the Creative Commons Attribution - NoDerivs (CC BY- ND 4.0) License http://creativecommons.org/licenses/by-nd/4.0/ 